\title{
Milk-borne bacterial health hazards in milk produced for commercial purpose in Tigray, northern Ethiopia
}

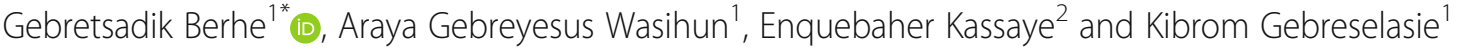

\begin{abstract}
Background: Milk being a suitable medium for bacterial growth, it can serve as a source of bacterial contamination. Pathogenic bacteria in milk pose a serious health threat to humans and constitute about $90 \%$ of all dairy-related diseases. However, there are few studies that examined the health hazards of raw milk consumption in Ethiopia. Therefore, the objective of this study was to assess the prevalence of bacterial contamination and associated factors in milk produced for commercial purpose in Tigray region, northern Ethiopia.

Methods: This study used a cross-sectional study design, selected 315 persons (168 cafeterias, 96 dairy farms, and 51 milk vendors) for interview and collected the same number of bulk raw milk samples using systematic sampling procedure. Data were collected on socio-demographic, farm hygiene and milk handling practices by trained health professionals. Bacterial contamination was defined as total bacterial count (TBC) $>1 \times 10^{5}$, staphylococcus count (SC) $>10^{5}$, or coliform count $(\mathrm{CC})>10^{2} \mathrm{CFU} / \mathrm{ml}$ by culture and the species of bacteria were determined by standard biochemical tests.
\end{abstract}

Results: From the 315 milk samples tested, the prevalence of bacterial contamination was 52\% (95\% Cl: 46.5-57.6). The mean counts of contaminated samples of TBC, SC, and CC were $8.94 \pm 0.46$ Standard Deviation (SD), $8.52 \pm 0.6$ $\mathrm{SD}$, and $8.78 \pm 0.49 \mathrm{SD} \log \mathrm{CFU} / \mathrm{ml}$, respectively. The proportion of contamination was significantly lower in milk collected from dairy farms (32/96, 33.3, 95\% Cl: 24.5-43.2) compared to milk from vendors (33/51, 64.7, 95\% Cl: 51.4-66.2) and cafeterias (99/168, 58.9, 95\% Cl, 50.9-76.85). The milk samples were culture-positive for Escherichia coli, Klebsiella pneumoniae, Staphylococcus aureus, K. oxytoca and Citrobacter freundii.

Conclusions: Over half of the sampled raw milk exhibited bacterial contamination with increasing trend from farmers to points of sale. Thus, milk vendors and cafeteria owners should apply good hygienic and sanitation practices during handling of milk; use appropriate, clean containers, and cold chain during milk transportation; and refrigeration of milk during storage.

Keywords: Bacteria, Commercial, Health-hazards, Milk-borne, Tigray

\footnotetext{
* Correspondence: gebretsadik_b@yahoo.com

${ }^{1}$ College of Health Sciences, Mekelle University, Mekelle, Ethiopia

Full list of author information is available at the end of the article
}

(c) The Author(s). 2020 Open Access This article is licensed under a Creative Commons Attribution 4.0 International License, which permits use, sharing, adaptation, distribution and reproduction in any medium or format, as long as you give appropriate credit to the original author(s) and the source, provide a link to the Creative Commons licence, and indicate if changes were made. The images or other third party material in this article are included in the article's Creative Commons licence, unless indicated otherwise in a credit line to the material. If material is not included in the article's Creative Commons licence and your intended use is not permitted by statutory regulation or exceeds the permitted use, you will need to obtain permission directly from the copyright holder. To view a copy of this licence, visit http://creativecommons.org/licenses/by/4.0/ The Creative Commons Public Domain Dedication waiver (http://creativecommons.org/publicdomain/zero/1.0/) applies to the data made available in this article, unless otherwise stated in a credit line to the data. 


\section{Background}

Milk and dairy products are important source of vital nutrients for human beings $[1,2]$. The unique composition and properties make milk an excellent medium for bacterial growth and source of bacterial infection [3]. Milk-borne pathogenic bacteria pose a serious threat to human health, and constitute about 90\% of all dairy- related diseases [4]. Staphylococcus aureus, Salmonella spp., Listeria monocytogenes, Escherichia coli O157:H7 and Campylobacter are the main microbiological hazards associated with raw milk consumption [3]. Microbiological status of raw milk is affected by several factors including a health status of the animal, farm management practices, environmental hygiene and poor temperature control [5].

In some countries with low socio-economic status, income growth and urbanization has led to almost doubled consumption of milk and dairy products [1, 2]. In Ethiopia, as the dairy industry is developing towards a market-oriented system, majority of milk vendors and cafeterias collect unpasteurized milk from different dairy farms to sell it to consumers [6]. A survey conducted in central Ethiopia reported that $31.8 \%$ of farmers consumed raw milk [7]. In the milk market value chain, milk handled in unhygienic way can be easily contaminated by milk-borne bacterial pathogens and serve as a suitable vehicle for disease transmission, causing a significant public health threat to consumers [6-8]. A study documented that hygienic practices during milking, handling and storing of milk were substandard resulting in poor quality milk products and safety problems [9]. A study conducted in northern Ethiopia reported milk contamination rate varying from 45 to $75 \%$ [10]. '.

In Tigray region, where less than $1 \%$ of the milk produced for commercial purpose is pasteurized and in situation where there is no set standard and regulation to control the safety and quality of milk produced for commercial purpose, the risk of milk contamination is high. Despite this fact, there are few studies that examined the health hazards of raw milk consumption in the study area, other than those conducted in localized areas with a small sample size. This study is expected to fill the gap in information on the magnitude and type of hazards associated with raw milk consumption and outline measures that are needed to be taken by milk producers, vendors and regulators to ensure the safety and quality milk in the milk supply value chain.

Therefore, the objective of this study was to assess the prevalence of milk-borne bacterial hazards and associated factors in commercially marketed raw milk in the Tigray regional state, Ethiopia.

\section{Methods}

\section{Study design and setting}

This study used a cross-sectional study design to assess the magnitude of milk-borne bacterial pathogens and associated factors in the study area during February to May 2017.

\section{Study area}

Tigray regional state is located in the northernmost part of Ethiopia. The region has a total population of $6.2 \mathrm{mil}-$ lion, $85 \%$ of which live in the rural areas and about $83 \%$ of the populations were farmers [11]. This study was carried out in the three big cities of the regional state; Mekelle, Wukro and Adigrat. Mekelle is the capital city of the region and Adigrat is the zonal capital for the eastern zone of the Tigray region [11].

\section{Source and study population}

The source populations were all dairy farmers, milk vendors, and cafeterias who sold milk in different forms in the three selected cities. The study populations were all dairy farmers, milk vendors, and cafeterias who sold milk in different forms in the selected lowest administrative units (Kebelles) in Mekelle, Wukro and Adigrat cities during the study period.

\section{Sample size determination and sampling procedure}

Sample size was estimated using a single population proportion formula with the following assumption: Confidence level $=95 \%$, prevalence $=0.75[10]$, margin of error $=0.05$. Thus, the total sample size was calculated as 288 study subjects and milk samples. We allocated the sample size using proportional to population size of the randomly selected ten Kebelles from Mekelle and four Kebelles from each of the two other study sites. In all the selected Kebelles, systematic random sampling was used to select dairy farmers, milk vendors or cafeterias.

\section{Data collection tools and methods Questionnaire survey}

The instrument used for this study was developed by modifying from other studies [7-10, 12, 13]. The investigators used a pre-tested structured questionnaire and administered it through face-to-face interviews with dairy farmers, milk vendors, and cafeteria owners after obtaining written informed consent from each study subject. Checklist was also used to assess the farm hygiene status. Data were collected on socio-demographic factors, milking, milk handling and storage practices. Data collectors were trained on the objective of the study, content, and method of administration of the tool. Data were collected by BSc level health professionals under close supervision. 


\section{Milk sample collection and laboratory examination}

A total of 315 milk samples were collected from all enrolled dairy farmers (96), milk vendors (51), and cafeterias (168) by conducting house-to-house visits. About $30 \mathrm{~mL}$ of bulk milk samples were collected aseptically from the containers used for storage of milk, put into a sterile universal bottle and placed in a cool box packed with ice packs. Milk samples were transported from the field to the laboratory within four hours of collection and stored at $4{ }^{\circ} \mathrm{C}$ in a refrigerator until testing.

\section{Laboratory tests for bacterial isolation and identification}

To determine the bacteriological quality of the raw cow milk, total bacterial count (TBC), staphylococcus spp. count (SC) and coliform count (CC) were performed. Plate Count agar (HiMedia, India), the Baired-Parker Agar Base (Oxoid, UK) enriched with Egg Yolk Tellurite Emulsion (Damstadt, Germany) and the Violet Red Bile agar (MiMedia, India) were used for each procedure, respectively. Peptone water was used as a diluent for serial ten-fold dilutions.

The enumeration of total viable bacteria, staphylococcus spp. and coliform bacteria were performed following standard procedures $[14,15]$. To describe briefly, for each sample a tenfold serial dilution, up to $10^{-6}$ dilutions were prepared using peptone water. From each dilution, $1 \mathrm{ml}$ was put in the center of the respective agar plates using micropipette and spread evenly to the whole plate using sterile bent glass rod. For each serial dilution, duplicate agar plates were employed. The inoculated agar plates were incubated at $37^{\circ} \mathrm{C}$ for $24-48 \mathrm{~h}$. Agar plates with 30-300 colonies were counted using colony counter as per the recommendation $[14,15]$. For identification of bacteria to species level, colony morphology and different primary and secondary biochemical testes were employed. The detailed laboratory procedures used for isolation and identification of the bacteria is described elsewhere [5, 6, 14-19].

\section{Data management and analysis}

The investigators entered the data into Epidata software and exported it to SPSS version 20 for analysis. Bacterial counts data were transformed to logarithm of colony forming units per milliliter of sample $(\log \mathrm{CFU} / \mathrm{ml})$ and the results were presented as mean \pm standard error $(\mathrm{SE})$, median with interquartile range (IQR) and percentage (\%). Bacterial contamination level in cow milk was graded according to the Standard European Union (EU) microbiological limits (TBC $\leq 1 \times 10^{5} \mathrm{CFU} / \mathrm{mL}, \mathrm{SC}<10^{5}$ $\mathrm{CFU} / \mathrm{mL}$ and $\mathrm{CC} \leq 10^{2} \mathrm{CFU} / \mathrm{mL}$ ) [20]. Descriptive statistics were calculated using simple frequencies, percentages, and mean. Bivariate and multivariable logistic regressions were used to identify factors associated with milk-borne bacterial hazards by controlling the confounding effect of selected variables. Statistical significance was determined by $p$ values, crude odds ratio (COR) and adjusted odds ratio (AOR) with their corresponding 95\% confidence intervals.

\section{Ethical considerations}

Ethical clearance was obtained from the Ethical Review Board of the College of Health Sciences, Mekelle University. All the study subjects in this study were adults above 20 years old. The investigators administered written informed consent to all study subjects after provision of information on the study. The autonomy of study participants was ensured and all collected data were kept confidential.

\section{Results}

\section{Socio-demographic characteristics of the study population}

Data were collected from a total of 315 study subjects (96 dairy farmers, 51 milk vendors, and 168 cafeterias) in the three selected study sites. The median age of study participants was 37 years (IQR $=31-43$ years) and ranged from 20 to 75 years. The highest number of study participants was from Mekelle city and the lowest from Wukro city. Male participants accounted for $55.6 \%$ of the study subjects (Table 1 ).

Table 1 Socio-demographic characteristics of study participants in the study area in 2017

\begin{tabular}{|c|c|c|c|}
\hline Variable & Categories & Frequency & Percent \\
\hline \multirow[t]{3}{*}{ Residence } & Mekelle & 182 & 57.8 \\
\hline & Wukro & 25 & 7.9 \\
\hline & Adigrat & 108 & 34.3 \\
\hline \multirow[t]{2}{*}{ Age } & $20 \leq 37$ & 177 & 56.2 \\
\hline & $38-75$ & 138 & 43.8 \\
\hline \multirow[t]{2}{*}{ Sex } & Males & 175 & 55.6 \\
\hline & Females & 140 & 44.4 \\
\hline \multirow[t]{3}{*}{ Level of education } & illiterate & 24 & 7.6 \\
\hline & 1-8th Grade & 171 & 54.3 \\
\hline & 9th grade and above & 120 & 38.1 \\
\hline \multirow[t]{4}{*}{ Marital status } & Single & 94 & 29.8 \\
\hline & Married & 209 & 66.3 \\
\hline & Divorced & 12 & 3.8 \\
\hline & Widowed & 0 & 0 \\
\hline \multirow[t]{4}{*}{ Occupation } & Dairy farmers & 81 & 28.7 \\
\hline & Cafeterias & 155 & 49.2 \\
\hline & Milk vendors & 47 & 14.9 \\
\hline & Others & 32 & 10.2 \\
\hline \multirow[t]{2}{*}{ Type of Businesses } & Dairy Farmers & 96 & 31.5 \\
\hline & Vendors and cafeterias & 219 & 69.5 \\
\hline
\end{tabular}


From the 96 dairy farmers who practiced cleaning of utensils, 44.4\% (43/96) used cold water and soap for washing utensils while $13.5 \%$ (13/96) used only cold water. All of the interviewed dairy farmers reported that they washed hands before milking and 68.8\% (66/96) used cold water and soap for washing their hands. The udders of lactating cows were washed with cold water by $46.2 \%$ of the famers. All dairy farmers reported that they filtered the milk after milking and before selling to consumers. To transport milk to their customers, $69.7 \%$ of the dairy farmers reported that they used narrow necked plastic vessels and $25.0 \%$ used wide neck plastic vessels. Transporting the milk to market was done mainly on foot $(57.3 \%)$ and bicycles (16.7\%). The source of drinking water for the farms was mainly tap water $(68.8 \%)$ followed by wells (16.7\%) (Table 2).

As regards to milk deliveries, about half $(53.2 \%)$ of milk vendors and cafeterias received milk in the morning and in the afternoon, $43.1 \%$ of them received in the early morning and $3.7 \%$ received in the afternoon. Nearly half $(48.6 \%)$ of the milk delivery was from one dairy farm. Moreover, $36 \%$ of milk vendors and cafeteria stored milk in a refrigerator and $23 \%$ of them stored it at room temperature. It was also found that $50 \%$ of the respondents had encountered milk spoilage (Table 3).

\section{Prevalence of bacterial contamination of milk}

The prevalence of bacterial contamination of milk was 52\% (95\% CI: 46.5-57.6). The recorded proportion of contamination was highest in milk collected from vendors $(33 / 51,64.7 \%)$, followed by cafeterias (99/168, $58.9 \%$ ) and dairy farms (32/96, 33.3\%) (Fig. 1). However, there was no statistically significant difference in the proportion of contamination between milk collected from cafeterias (64.7, 95\% CI: 50.9-76.85) and milk vendors (58.9, 95\% CI: 51.4-66.2). Moreover, there was no significant variation in the proportion of milk contamination among milk collected from the three cities: Mekelle (56.6, 95\% CI: 49.3-63.7), Wukro (48.0, 95\% CI: 32.8-70.8) and Adigrat cities (45.4, 95\% CI: 36.2-54.8).

Of the 315 cultured samples, $52.1 \%$ (164) of the total bacterial count and 40.6\% (128) of Staphylococcus count exceeded the threshold limit of acceptable quality of milk and thus graded as contaminated or poor quality. Similarly, $47.9 \%$ (151) coliform counts had microbial count in excess of $\leq 10^{2} \mathrm{CFU} / \mathrm{ml}$. The mean of contaminated total bacterial count, staphylococcus spp. count and coliform count was $8.94 \pm 0.46$ (Std. dev.), $8.52 \pm 0.6$ (Std. dev.) and $8.78 \pm 0.49$ (Std. dev.) $\log \mathrm{CFU} / \mathrm{ml}$ of milk, respectively.

The milk samples were culture-positive for E. coli, $K$. pneumoniae and S. aureus, $K$. oxytoca and $C$. freundii. Among the identified bacteria, E. coli (21.3\%), K.
Table 2 Hygienic practices of dairy farmers in the study area in 2017

\begin{tabular}{|c|c|c|c|}
\hline No. & Description of variable & Frequency & Percent \\
\hline \multirow[t]{5}{*}{1} & Cleaning of utensils & & \\
\hline & Cold water & 13 & 13.5 \\
\hline & Soap and cold water & 43 & 44.8 \\
\hline & Soap and hot water & 39 & 40.6 \\
\hline & Only hot water & 1 & 1.0 \\
\hline \multirow[t]{5}{*}{2} & Hand washing & & \\
\hline & Cold water & 18 & 18.8 \\
\hline & Soap and cold water & 66 & 68.8 \\
\hline & Soap and hot water & 10 & 10.4 \\
\hline & Only hot water & 2 & 2.1 \\
\hline \multirow[t]{5}{*}{3} & Udder washing & & \\
\hline & Cold water & 46 & 47.9 \\
\hline & Soap and cold water & 9 & 9.4 \\
\hline & Soap and hot water & 24 & 25 \\
\hline & Only hot water & 17 & 17.7 \\
\hline \multirow[t]{5}{*}{4} & Containers used for transportatio & f milk & \\
\hline & Wide necked aluminum vessel & 3 & 3.03 \\
\hline & Narrow necked aluminum vessel & 0 & 0 \\
\hline & Narrow necked plastic vessel & 69 & 69.7 \\
\hline & Wide neck plastic vessel & 24 & 25.0 \\
\hline \multirow[t]{5}{*}{5} & Means of milk transport & & \\
\hline & Cars & 11 & 11.5 \\
\hline & Bicycle & 16 & 16.7 \\
\hline & Bajaj or Motorcycle & 14 & 14.6 \\
\hline & On Foot & 55 & 57.3 \\
\hline \multirow[t]{4}{*}{6} & Sources of water & & \\
\hline & Tap water & 66 & 68.8 \\
\hline & Wells & 16 & 16.7 \\
\hline & Ponds and streams & 14 & 14.6 \\
\hline \multirow[t]{4}{*}{7} & Milk storage container & & \\
\hline & Plastic container & 92 & 94.8 \\
\hline & Stainless steel container & 2 & 2.1 \\
\hline & Aluminum container & 2 & 2.1 \\
\hline
\end{tabular}

pneumoniae (14.6\%) and S. aureus (11.4\%) were isolated with highest proportion (Fig. 2).

Factors associated with bacterial contamination of milk In the bivariate and multivariable logistic regression analysis; variables including residence, age, sex, educational status, marital status and type of business were analyzed for possible association with contamination of milk. In the bivariate analysis, although the OR for 1-8th grade educational level was greater than one, the $95 \%$ confidence interval (0.58-3.39) was statistically insignificant. 
Table 3 Milk handling practices of milk vendors and cafeterias in the study area in 2017

\begin{tabular}{|c|c|c|}
\hline Description of variable $(\boldsymbol{n}=216)$ & Frequency & Percent \\
\hline \multicolumn{3}{|l|}{ Time of milk collection } \\
\hline Evening & 8 & 3.7 \\
\hline Early morning & 93 & 43.1 \\
\hline Both & 115 & 53.2 \\
\hline \multicolumn{3}{|l|}{ Sources of milk } \\
\hline Own farm & 30 & 13.8 \\
\hline Other one farm & 105 & 48.6 \\
\hline Other two farms & 38 & 17.6 \\
\hline Other three or more farms & 40 & 18.5 \\
\hline Milk vendors & 3 & 1.4 \\
\hline \multicolumn{3}{|l|}{ Type of milk sold } \\
\hline Raw milk & 7 & 3.2 \\
\hline Boiled milk & 69 & 31.9 \\
\hline Yogurt & 11 & 5.1 \\
\hline Boiled milk and yoghurt & 84 & 38.9 \\
\hline Raw milk, boiled milk and yogurt & 45 & 20.8 \\
\hline \multicolumn{3}{|l|}{ Milk storage } \\
\hline Refrigerator & 78 & 36.1 \\
\hline Room temperature & 49 & 22.7 \\
\hline Boiling and room temperature & 13 & 6.0 \\
\hline Boiling and refrigeration & 76 & 35.2 \\
\hline \multicolumn{3}{|l|}{ Time to finish the milk } \\
\hline One day after collection & 137 & 63.4 \\
\hline Two days after collection & 76 & 35.2 \\
\hline More than 2 days after collection & 3 & 1.4 \\
\hline \multicolumn{3}{|l|}{ Incident of milk spoiling } \\
\hline Yes & 108 & 50 \\
\hline No & 108 & 50 \\
\hline
\end{tabular}

Similarly, sex and marital status were not significantly associated with increased prevalence of bacterial contamination. However, type of business was statistically associated with milk contamination both in the bivariate and multivariable logistic regression analysis. Milk collected from milk vendors and cafeteria owners were nearly three times more contaminated (AOR $=2.72,95 \%$ $\mathrm{CI}=1.60-4.61)$ as compared to milk sampled from dairy farmers (Table 4).

\section{Discussion}

This study reported a higher prevalence of bacterial contamination of milk (52\%). The prevalence of milk-borne bacterial contamination of milk is similar to a report from Adigrat city where milk contamination rate was $45 \%$ in farm settings, $60 \%$ in milk vendor shops and $75 \%$ in cafeterias [10]. In terms of $S$. aureus contamination level, it was lower than the prevalence of $S$. aureus (19.6\%) reported in Central Oromia [21] and Tigray region (38.7\%), Ethiopia [6]. Similarly, this study recorded lower contamination level comparing to a report from Côte d'Ivoire where $76.5 \%$ of the samples showed the presence of one or more of the three pathogens (E. coli, S. aureus, and Enterococcus) [22]. Moreover, higher rate of contamination of milk was reported from another study in India [23]. Possible reasons for this high level of milk contamination in the study area could be attributed to the use of un-pasteurized milk for commercial purposes, sub-optimal hygiene practices, inadequate cooling and lack of standard facilities for milking, storage, and transportation of milk. There is considerable evidence that microbial contamination in the milk market value chain can originate from a diseased cow, unhygienic milking practice, poor personal hygiene, unsanitary utensils and/or milking equipment, poor storage conditions, and lack pure water supply [24, 25]. A study reported that in developing countries like Ethiopia, there are inadequate hygienic practices throughout the dairy production system and standard milking protocols do not exist which is evidenced by the presence of many dairy farmers that do not disinfect teats prior to milking and inadequate washing of hands before milking [26, 27].

From the total cultured milk samples, 47.9 and $40.6 \%$ were isolates of coliform and $S$. aureus, respectively. Coliform counts are important indicators that are used to measure the level of microbial quality and hygiene in milk handling [28, 29]. Previous studies have also indicated that coliform and staphylococcus are the most frequent bacterial contaminants of milk and this was attributed to their abundant availability both in the animal body and in the environment $[29,30]$. In this study, more than $31 \%$ of the dairy farms have been using rivers, ponds or wells as their source of water and this might have contributed to the high coliform contamination of milk in our study. Contamination of $S$. aureus can arise from various sources as the bacteria is commonly found on the various body parts of warm blooded animals and it can be isolated from faeces, soil and fresh water [25]. Moreover, $S$. aureus can be carried in approximately $20-50 \%$ healthy individuals in their nasal cavity [31].

The high bacterial contamination rate of milk in our study implies that milk can pose health risks to consumers. If milk is not handled properly and in hygienic condition, it will support the growth of pathogenic micro-organisms leading to transmission of zoonotic and foodborne diseases that can compromise the health of the population. Therefore, to prevent contamination of milk by pathogenic micro-organism, improving animal health, environmental hygiene, dairy farming practices, milk handling, transportation and storage practices are required $[28,32]$. 


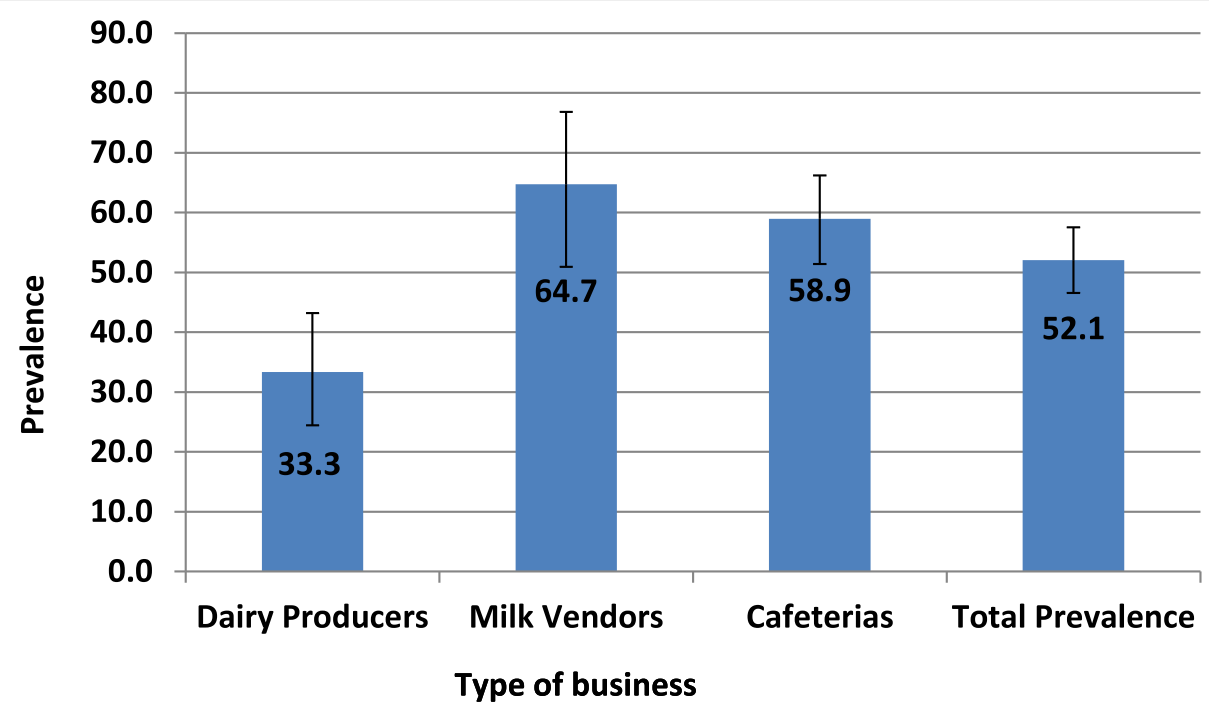

Fig. 1 Prevalence of bacterial contamination by types of business in the study area in 2017

Among the socio-demographic factors evaluated for association with milk contamination, type of business was significantly associated with higher level of milk contamination. The proportion of milk contamination was significantly lower in milk collected from dairy producers (33.3, 95\% CI: 24.5-43.2) compared to milk from vendors and cafeterias. This is consistent with the findings of Merhawit et al. [10] and Oliver et al. [33] where the bacteriological quality of milk deteriorated along the milk supply chain due to the proliferation of the microorganisms initially present in the milk or/and due to cross contamination [4]. As there was increasing trend of milk contamination from farmers to points of sale, milk vendors and cafeterias should use appropriate and clean containers, timely delivery of milk, cold chain during transportation, and refrigeration of milk during storage.

Throughout the developing world, over $80 \%$ of the milk consumed is unregulated, and in Ethiopia less than $1 \%$ of the milk consumed is pasteurized [34, 35]. It is reported that the contamination of milk is high in countries where there is traditional farming systems and market is unregulated. Increased contamination level of milk along the milk market chain indicates that food safety is becoming an important public health agenda particularly in milk produced for commercial purpose. When milk is produced for commercial purpose with inadequate hygienic practices, milk contaminated with pathogenic micro-organisms can end-up with mass distribution, mass outbreaks affecting more people and

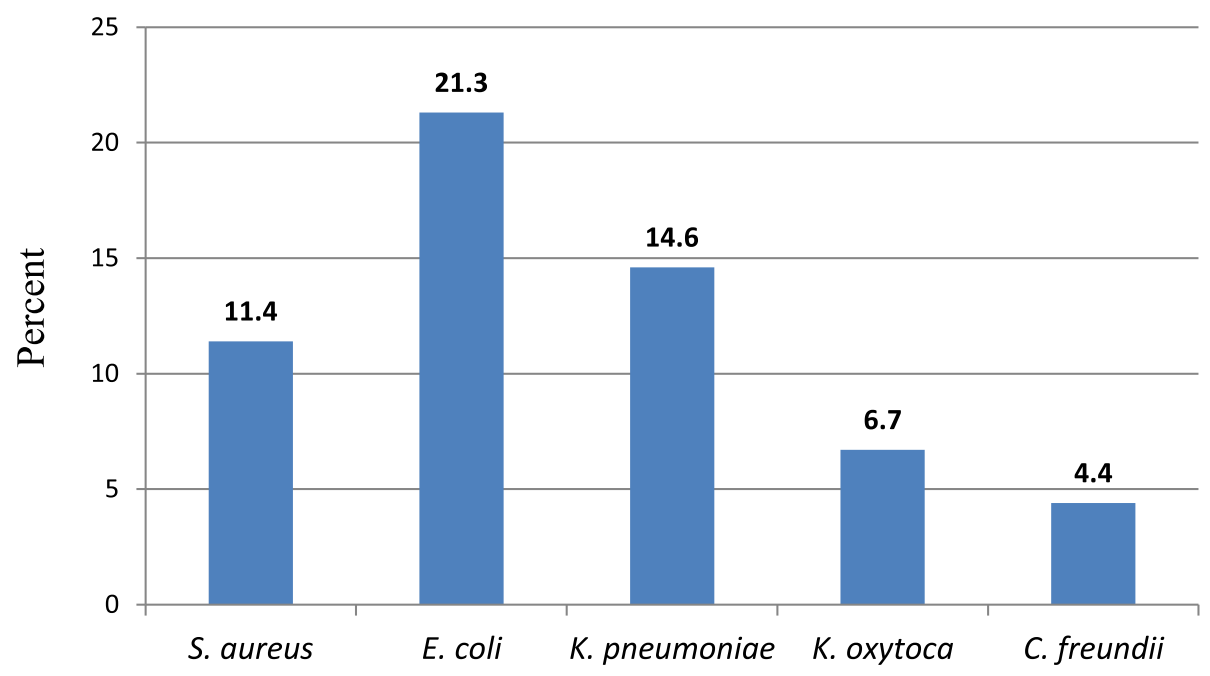

Fig. 2 Type and proportion of isolated bacteria from milk samples collected from the study area in 2017 
Table 4 Factors associated with increased prevalence of bacterial contamination of milk in the study area in 2017

\begin{tabular}{|c|c|c|c|c|c|c|}
\hline Variable & Positive (\%) & Negative (\%) & COR & $95 \% \mathrm{Cl}$ & AOR & $95 \% \mathrm{Cl}$ \\
\hline \multicolumn{7}{|l|}{ City } \\
\hline Mekelle & $103(32.7)$ & $79(25.1)$ & 1 & & & \\
\hline Adigrat & 49 (15.6) & 59 (18.7) & 0.708 & $0.306-1.63$ & & \\
\hline Wukro & $12(3.8)$ & $13(4.1)$ & 1.11 & $0.465-2.65$ & & \\
\hline \multicolumn{7}{|l|}{ Age } \\
\hline $20 \leq 37$ & $95(30.2)$ & $82(26.0)$ & 1 & & & \\
\hline $38-75$ & $69(21.9)$ & 69 (21.9) & 0.863 & $0.55-1.35$ & & \\
\hline \multicolumn{7}{|l|}{ Sex } \\
\hline Male & $84(26.7)$ & $91(28.9)$ & 1 & & 1 & \\
\hline Female & $80(25.4)$ & $60(19.0)$ & 1.44 & $0.924-2.26$ & 1.01 & $0.618-1.67$ \\
\hline \multicolumn{7}{|l|}{ Educational status } \\
\hline Illiterate & $10(3.2)$ & $14(4.4)$ & 1 & & & \\
\hline 1-8th grade & $94(29.8)$ & $77(24.4)$ & 1.4 & $0.577-3.39$ & & \\
\hline 9th grade and above & $60(19.0)$ & $60(19.0)$ & 0.819 & $0.513-1.31$ & & \\
\hline \multicolumn{7}{|l|}{ Marital status } \\
\hline Single & $61(19.4)$ & $33(10.5)$ & 1 & & 1 & \\
\hline Married & $98(31.1)$ & $111(35.2)$ & 0.386 & $0.144-1.31$ & 0.542 & $0.152-1.94$ \\
\hline Divorced & $5(1.6)$ & $7(2.2)$ & 0.809 & $0.249-2.63$ & 0.892 & $0.260-3.06$ \\
\hline \multicolumn{7}{|l|}{ Type of Business } \\
\hline Dairy farmers & $33(10.5)$ & $63(20.0)$ & 1 & & 1 & \\
\hline Vendors and Cafeterias & $131(41.6)$ & $88(27.9)$ & 3.08 & $1.87-5.08$ & 2.72 & $1.60-4.61$ \\
\hline
\end{tabular}

cause a greater economic impact. Therefore, focus needs to be placed on setting food safety standards particularly for milk produced for commercial purpose [4]. Generally, the implementation of good hygienic practice and sanitation, introduction of quality and safety standards as well as the use of an effective cold chain and pasteurization technologies are the key measures to improve the microbial quality and safety of the milk.

This study was conducted in a large milk-shed area using adequate sample size. As limitation, this study didn't comprehensively examine all important bacterial contaminants of milk and factors responsible for milk contamination. Moreover, residual confounding and social desirability bias might have occurred during variables measurement.

\section{Conclusions}

The following conclusions are made from this study:

The level of milk contamination in this study was high indicating the presence of significant health risks to the consumer. Milk collected from milk vendors and cafeterias was significantly associated with higher level of milk contamination compared to milk sampled from dairy farms.

Therefore, considering the study findings, the following recommendations are made.

Milk vendors and cafeteria owners should apply good hygienic and sanitation practices during handling of milk; use appropriate, clean containers, and cold chain during transportation; and refrigeration of milk during storage. Governmental bodies should set quality and safety standards for milk produced for commercial purpose to improve microbial quality and safety of milk. Further research is required to assess contamination of milk by other important pathogens particularly Salmonella spp., Campylobacter spp., L. monocytogenes spp.

\section{Abbreviations}

AOR: Adjusted Odds Ratio; COR: Crude Odds ratio; CC: Coliform count; CFU: Colony forming unit; Cl: Confidence interval; SC: Staphylococcus count; TBC: Total bacterial count

\section{Acknowledgements}

The authors would like to thank Mekelle University for providing facilities for laboratory testing.

\section{Authors' contributions}

GB: Conceptualization, investigation, designed the methodology, did statistical analysis, wrote original draft, reviewed and edited final draft. AG: Investigation, designed methodology, performed laboratory analysis, and wrote original draft. EK: Participated in conceptualization, methodology design and investigation. KG: Participated in conceptualization and investigation. All authors have read and approved the final manuscript.

\section{Funding}

This research work was funded by the One Health Central and Eastern Africa (OHCEA) Workforce Project. However, the institution didn't have any role in the design of the study, data collection, analysis, interpretation of data and in writing the manuscript. 


\section{Availability of data and materials}

The datasets used and/or analyzed during the current study are available from the corresponding author on reasonable request.

\section{Ethics approval and consent to participate}

The study was approved by the Institutional Review Board of the College of Health Sciences, Mekelle University. Written informed consent was obtained from all study participants. The ethical approval/permission was based on a letter reference number ERC 0905/2017 approved on 25/01/2017.

\section{Consent for publication}

Not applicable.

\section{Competing interests}

"The authors declare that they have no competing interests".

\section{Author details}

${ }^{1}$ College of Health Sciences, Mekelle University, Mekelle, Ethiopia. ${ }^{2}$ College of Veterinary Medicine, Mekelle University, Mekelle, Ethiopia.

Received: 25 February 2019 Accepted: 29 May 2020

Published online: 09 June 2020

\section{References}

1. FAO (Food and Agriculture Organization). Status of and prospects for smallholder milk production - A Global Perspective, by T. Hemme and J Otte Rome, 2010. 1 - 5 .

2. Fusco V, Quero GM. Culture-dependent and culture-independent nucleicacid- based methods used in the microbial safety assessment of Milk and dairy products. Compr Rev Food Sci Food Saf. 2014;13:493-537.

3. Claeys W, Cardoen S, Daube G, De Block J, Dewettinck K, Dierick K. Raw or heated cow milk consumption: Review of risks and benefits. Food Control. 2013;31:251e262.

4. Ryser ET. Public Health Concerns. In: Applied Diary Microbiology; Steele Edition. New York: Mercell Dekker, Inc; 1998. p. 263-404.

5. Food Standards Australia New Zealand. Microbiological risk assessment of raw cow milk. Risk Assessment Microbiology Section 2009.

6. Enquebaher T, Siv S, Knut R, Taran S, Narvhus JA. Staphylococcus aureus and other Staphylococcus species in milk and milk products from Tigray region, Northern Ethiopia. Afr J Food Sci. 2015;9(12):567-76.

7. Makita K, Desissa F, Teklu A, Zewde G, Grace D. Risk assessment of staphylococcal poisoning due to consumption of informally-marketed milk and home-made yoghurt in Debre Zeit, Ethiopia. Int J Food Microbiol. 2012; 153:135-41.

8. Angulo FJ, LeJeune JT, Rajala-Schultz PJ. Unpasteurized Milk: a continued public health threat. Clin Infect Dis. 2009;48:93-100.

9. Zelalem Y, Bernard F. Handling and microbial load of cow's milk and Irgofermented milk collected from different shops and producers in central highlands of Ethiopia. Eth J Anim Prod. 2006;6(2):67-82.

10. Merhawit R, Habtamu T, Berihun A, Abrha B. Bacteriological quality assessment of milk in dairy farms, cafeterias and wholesalers in Adigrat, Tigray, Ethiopia. Eur J Biol Sci. 2014;6(4):88-94.

11. Tigray online, 2107. Tigrai State, The open-air Museum. http://www. tigraionline.com/tigraistate.html Accessed on 03/01/2017.

12. Ewa Z, Jan G, Magdalena T. Food-borne pathogens and contaminants in raw milk -a review. Ann Anim Sci. 2016;16(3):623-39.

13. Shija F. Assessment of milk handling practices and bacterial contaminations along the dairy value chain in Lushoto and Handeni districts, Tanzania. In: A dissertation submitted in partial fulfillment of the requirements for the degree of Master of Science in public health and food safety of Sokoine University of Agriculture. Morogoro, Tanzania; 2013.

14. American Public Health Association (APHA). Standard method for the examination of dairy products. Washington: APHA; 1992.

15. Yousef $A E$, Carlstrom C. Food Microbiology: A Laboratory Manual. The Ohio State University. ISBN 13: 978-0-471-39105-0. Hobohen: Wiley; 2003.

16. ISO/FDIS, Milk and milk products-general guidance for the preparation of samples, initial suspensions and decimal dilutions for microbiological examination, International Organization for Standardization, Geneva, 2001.

17. ISO (International Organization for Standardization). PN-EN ISO 6888-1: microbiology of food and animal feeding stuffs-horizontal method for the enumeration of coagulase-positive staphylococci (Staphylococcus aureus and other species)-part 1: technique using Baird-Parker agar medium. Geneva: ISO; 2001.

18. ISO (International Organization for Standardization). PN-ISO16649-2: microbiology of food and animal feeding stuffs - horizontal method for the enumeration of beta-glucuronidase-positive Escherichia coli-part 2: Colonycount technique at 44 degrees C using 5-bromo-4-chloro-3-indolyl beta-Dglucuronide. Geneva: ISO; 2004b.

19. ISO 7218:2007, "(International Standards Organisation). Microbiology of food and animal feeding stuffs- general requirements and guidance for microbiological examination, No. 7218; 2007. p. 8-15.

20. European Union (EU). Regulation (EC) no 853/2004 of the European Parliament and of the council of 29 April 2004 laying down specific hygiene rules for food of animal origin. Off J Eur Union. 2004;139:22-82.

21. Yodit A, Fanta DG, Bedaso ME, Robel G, Takele BT, Tariku JB, Fanos T, Mesula G, Ashenafi FB. Assessment of Staphylococcus aureus along milk value chain and its public health importance in Sebeta, central Oromia, Ethiopia. BMC Microbiology. 17:141.

22. Kouamé-Sina SM, Makita K, Costard S, Grace D, Dadié A, Dje M, Bonfoh B. Hazard identification and exposure assessment for bacterial risk assessment of informally marketed milk in Abidjan, Côte d'Ivoire. Food Nutr Bull. 2012; 33(4):223-34.

23. Lingathurai $S$, Vellathurai $P$. Bacteriological quality and safety of raw cow Milk in Madurai, South India. Webmed Central Microbiology. 2010;1(10): WMC001029.

24. Kilango KG. Food Safety in Milk Markets of Smallholder Farmers in Tanzania: A Case of Peri Urban Wards in Temeke Municipality. In: Dissertation for Award of MSc. Degree at Sokoine University of Agriculture, Morogoro, Tanzania; 2011. p. 6.

25. Lubote R, Shahada F, Matemu A. Prevalence of Salmonella spp. and Escherichia coli in raw milk value chain in Arusha, Tanzania. Am J Res Commun. 2014;2(9):1-13.

26. Yilma Z. Quality Factors that Affect Ethiopian Formal Milk Business; Experiences from selected dairy potential areas. Addis Ababa: Netherlands Development Organization (SNV); 2010

27. Khan AA, Massod FA, Bhat BA. Bacteriological quality and safety of raw milk in Kashmir valley. Wayamba J Animal Sci. 2011;3:2102-5789.

28. Oliver SP, Jayarao BM, Almeida RA. Foodborne pathogens in milk and the dairy farm environment: food safety and public health implications. Foodborne Pathog Dis. 2005;2:115-29.

29. Pantoja JCF, Reinemann DJ, Ruegg PL. Factors associated with coliform count in unpasteurized bulk milk. J Dairy Sci. 2011;94:2680-91.

30. Stewart CM. Staphylococcus aureus and staphylococal enterotoxins. In: Foodborne Microorganisms of Public Health Significance, Ed: A. D. Hocking, 2003; 359-379. Australian Institute of Food Science and Technology: Waterloo.

31. Adams MR, Moss MO. Food Microbiology. 3rd Ed. Guildford: The Royal Society of Chemistry; 2008. Thomas Graham house, Science Park, Milton road, Cambridge CB4 OWF, UK.

32. Pell AN. Manure and microbes: public and animal health problem? J Dairy Sci. 1997:80:2673-81.

33. Oliver SP, Jayarao BM, Almeida RA. Foodborne pathogens in Milk and the dairy farm environment: food safety and public health implications. Foodborne Pathog Dis. 2015;2(2):115-29.

34. FAO. Animal Production and Health Division. Milk and dairy Products in human Nutrition. In: Muehlhoff E, Bennett A, McMahon D, editors. Food and Agriculture Organization of the United Nations; 2013.

35. Tambi E, Nicholson C, Staal S. Patterns of change in dairy production and consumption in developing countries from 1985 to 1998. Market-oriented Smallholder Dairy Research Working Document 7. Nairobi: ILRI (International Livestock Research Institute); 2001. p. 65.

\section{Publisher's Note}

Springer Nature remains neutral with regard to jurisdictional claims in published maps and institutional affiliations. 